\title{
A new species of Lagynochthonius (Pseudoscorpiones: Chthoniidae) from Yunnan Province, China
}

\author{
Junfang Hu \& Feng Zhang* \\ College of Life Sciences, Hebei University, Baoding, Hebei 071002, China \\ E-mail: jfanghu@gmail.com \\ *Corresponding author, E-mail: dudu06042001@163.com
}

\begin{abstract}
Lagynochthonius microdentatus sp. nov. is described and figured from Yunnan Province, China.
\end{abstract}

Key words - Pseudoscorpiones, Lagynochthonius, taxonomy, new species

\section{Introduction}

The pseudoscorpion genus Lagynochthonius belongs to tribe Tyrannochthoniini Chamberlin 1962, subfamily Chthoniinae Daday 1888, family Chthoniidae Daday 1888. At present this genus contains 43 species and is widely distributed in Asia, Australasia, Africa and South America (Harvey 2011). Pseudoscorpions of this genus generally have a bottle-shaped palpal palm, a greatly enlarged sclerotic apodeme of the movable finger, and the distal tooth of the fixed chelal finger displaced onto the antiaxial face.

To date, only two species have been reported from China: Lagynochthonius sinensis (Beier 1967) and $L$. tonkinensis (Beier 1951). In the present paper, we describe a new Lagynochthonius species, which was collected in leaf litter, from Yunnan Province, China.

\section{Materials and methods}

The patterns of description and the terminology follow Chamberlin (1931) and Harvey (1992). The term "rallum" (for flagellum) is adopted following Judson (2007). All specimens are preserved in $75 \%$ alcohol and were examined and illustrated under a Leica M165c stereomicroscope with a drawing tube, which was also used for the measurements. Microscopical examination was carried out with a Nikon YS100 general optical microscope. Temporary slide mounts were made in glycerol. All measurements are given in $\mathrm{mm}$. The types are deposited in the Museum of Hebei University (MHBU), Baoding City, China.

The following abbreviations are used in the text: for the trichobothria: $b=$ basal, $s b=$ sub-basal, $s t=$ subterminal, $t=$ terminal, $i b=$ interior basal, $i s b=$ interior sub-basal, ist $=$ interior sub-terminal, it $=$ interior terminal, $e b=$ exterior basal, esb $=$ exterior sub-basal, est $=$ exterior sub-terminal, et $=$ exterior terminal, $d x=$ duplex; for other parts: $t d=$ modified tooth, $p=$ proximal sensilla of movable chelal finger, $s c=$ chemosensory setae.
Taxonomy

Lagynochthonius microdentatus sp. nov.

(Figs. 1-19)

Type material. Holotype male: China, Yunnan Province: Dali City, entrance to Cangshan National Geological Park $\left(25^{\circ} 41^{\prime} \mathrm{N} 100^{\circ} 08^{\prime} \mathrm{E}\right)$, Cangshan Mountain, litter layer; 6 August 2010, Junfang Hu leg. Paratypes: 4 males, 8 females, collection data as for holotype.

Other material examined. 7 males, 7 females, Jingdong County, near hills of Wenlong Town $\left(24^{\circ} 38^{\prime} \mathrm{N} 100^{\circ} 44^{\prime} \mathrm{E}\right)$, litter layer, 3 August 2010, Junfang Hu leg.; 1 male, 8 females, Jinghong City, Xishuangbanna Primitive Forest Park $\left(22^{\circ} 02^{\prime} \mathrm{N} 100^{\circ} 50^{\prime} \mathrm{E}\right)$, in litter layer from forest, 18 July 2010, Junfang Hu leg.; 7 males, 2 females, 1 tritonymph, 1 deutonymph, Zhenyuan County, near hills of Gucheng Town $\left(23^{\circ} 43^{\prime} \mathrm{N} 101^{\circ} 08^{\prime} \mathrm{E}\right)$, litter layer, 28 July 2010, Junfang Hu leg.; 3 males, 2 females, Zhenyuan County $\left(23^{\circ}\right.$ $59^{\prime} \mathrm{N} 101^{\circ} 06^{\prime} \mathrm{E}$ ), near hills of Enle Town, litter layer, 29 July 2010, Junfang Hu leg.; 1 female, 1 tritonymph, Mengla County, Menglun Town, Green Stone Forest Park (21 ${ }^{\circ} 50^{\prime}$ $\mathrm{N} 101^{\circ} 24^{\prime} \mathrm{E}$ ), litter layer in forest, 21 July 2010, Junfang Hu leg.; 1 male, 1 female, Ning'er County, near hills of De'an Town $\left(23^{\circ} 25^{\prime} \mathrm{N} 101^{\circ} 11^{\prime} \mathrm{E}\right)$, litter layer, 26 July 2010, Junfang Hu leg.; 10 tritonymphs, Dali City, Cangshan National Geological Park, Cangshan Mountain, litter layer, 6 August 2010, Junfang Hu leg.

Etymology. The specific name is derived from the Latin "micro" and "dentatus" meaning small-toothed, referring to the small intercalary teeth on the fixed chelal finger.

Diagnosis. Carapace with four corneate eyes; epistome absent; tiny intercalary teeth on fixed chelal finger only; tergites I-IV with 4 setae.

Description. Carapace, chela, and femora and patellae of legs slightly blackened (Fig. 1). Carapace (Fig. 2) smooth, subquadrate, anterior margin denticulate (Fig. 3); anterior pair of eyes well developed, posterior pair of eyes with 
flattened lenses; epistomal region depressed with one seta on each side; with 16 macrosetae, of which 4 at anterior and 2 at posterior margin, one preocular microseta on each side. Tergal chaetotaxy: 4: 4: 4: 4: 4-6: 4-5: 4-6: 4-6: 5-7: 4-6: T2T (female: 4: 4: 4: 4: 5: 5-6: 5-6: 5-6: 6: 4-5: T2T). Coxa of palp with 5 setae ( 2 on manducatory process); coxa I with 3 setae and a short finger-like projection laterally (Fig. 9), II with 4 setae and 7-9 spines, arranged in an arc (Fig. 10), III and IV each with 5 setae. Intercoxal tubercle absent. Male anterior genital operculum (Fig. 17) with 8 setae; genital opening slit-like, with $6^{-7}$ marginal setae on each side, female anterior genital operculum (Fig. 14) with 8-9 setae plus $8^{-10}$ setae on posterior margin; sternites undivided, chaetotaxy of III-XII: $8-10+3-4$ stigmatic microsetae : 6 + 4: 10-11: 10-11:9-10: 9-11:9-13:9-10: 0: 2 (female: $8-9: 10+3$ stigmatic microsetae: $8-9+3$ : 11-12: 10-11: 10: 9-11: 10-12: 9-10: 0: 2).

Chelicera (Fig. 4) with 5 setae on palm and one median seta on movable finger. Fixed finger with $5^{-9}$ pointed teeth, apical tooth distinctly larger, movable finger with $8^{-12}$ small and pointed teeth, spinneret present, larger and more distinct in female (Fig. 18) than in male (Fig. 15). Serrula exterior with 18-19 lamellae, serrula interior with approximately 13 lamellae. Rallum (Fig. 13) composed of 8 blades, distal blade recumbent at base, with fine barbules and set apart from the other blades, the latter tightly grouped and with long pinnae, some of which are subdivided.

Palp (Figs. 5-8, 11-12) femur 2.8-3.1 times (male) 2.32.5 times (female) longer than patella; hand with a medial spine-like seta at level of ist, dorsal surface of hand with a single row of 5-6 chemosensory setae (sc) between trichobothria $e s b$ and $i b / i s b$; fixed finger with $14-15$ pointed teeth and 5-8 tiny intercalary teeth in distal section, movable finger with 7-9 pointed teeth (reaching slightly beyond midway between $b$ and $s b$ ) in distal section and without teeth in basal section; tip of fixed finger with a modified accessory tooth on dorso-antiaxial face (Fig. 7), situated slightly distal to $d x$ (Fig. 8); movable finger with a strong basal apodeme, sensilla $p_{1}$ and $p_{2}$ near trichobothrium $s b$ (Fig. 6), one pore (sense pore?) close to sensillum $p_{2}$. Trichobothrial pattern as illustrated (Fig. 6); $s b 0.5$ times nearer to $s t$ than to $b$.

Leg I (Fig. 16) femur 1.9-2.1 times (1.8-1.9 times in female) longer than patella and tarsus $2.1-2.2$ times $(2.1-2.3$ times in female) longer than tibia. Leg IV (Fig. 19) with a tactile seta on basitarsus (TS $=0.33$ ) and telotarsus (TS $=$ $0.23)$.

Tritonymph. Color much paler than adults. Palp: fixed chelal finger with 7 trichobothria and $d x$ present, moveable chelal finger with 3 trichobothria; $i s b$ and $s b$ absent. Fixed chelal finger with 13 teeth, plus 3-5 small intercalary teeth distally. Moveable chelal finger with $7-8$ teeth. Chelicera with 5 setae on hand; rallum of 7 blades. Carapace chaetotaxy: 4-2, 16. Tergal chaetotaxy: 4: 4: 4: 4: 4: 4: 4: 5: 5: 5: T2T: 0 . Sternal chaetotaxy: 5: $6+2$ stigmatic microsetae $: 6+2: 7: 7: 7: 7: 7: 6: 0: 2$. Coxal chaetotaxy

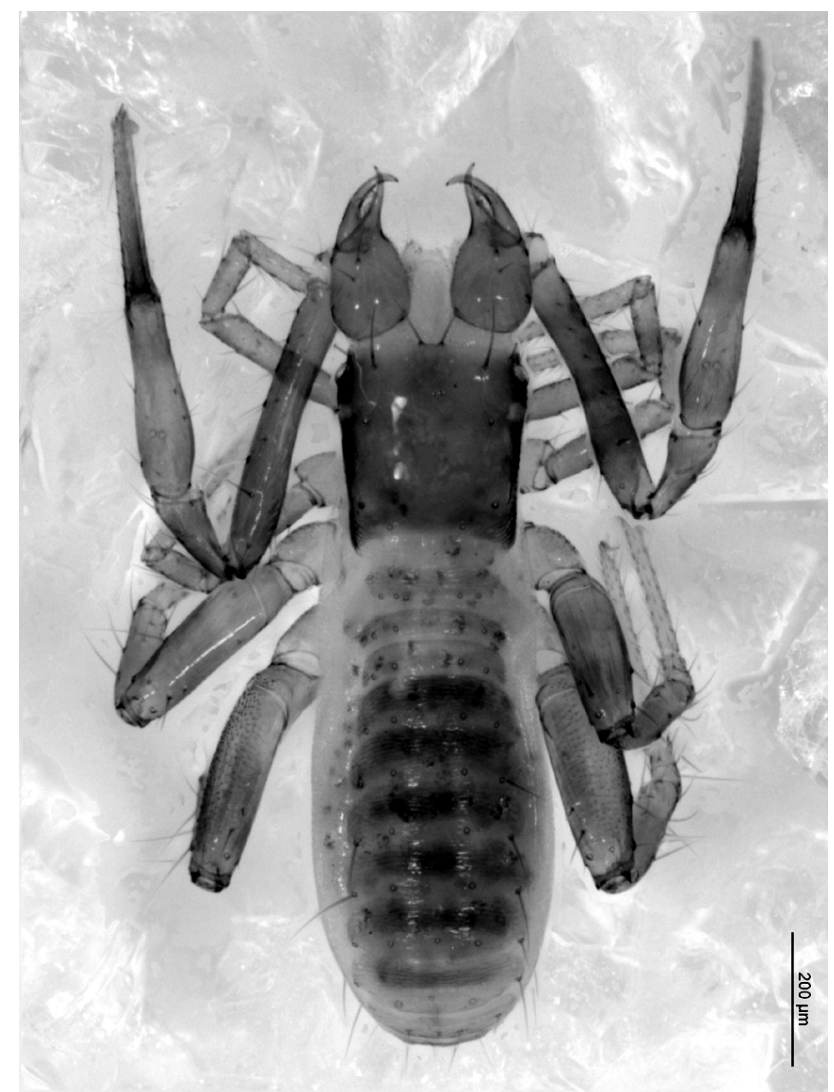

Fig. 1. Lagynochthonius microdentatus sp. nov., dorsal view of male holotype.

of legs: 3: 3: 4: 4; coxae II with 7-8 distally incised spines.

Deutonymph. Color very pale. Palp: fixed chelal finger with 6 trichobothria and $d x$ present, moveable chelal finger with 2 trichobothria; isb, ist, st and $s b$ absent. Fixed chelal finger with 10 teeth, plus 2-3 small intercalary teeth distally. Moveable chelal finger with 6 teeth. Chelicera with 4 setae on hand; rallum of 6 blades. Carapace chaetotaxy: 4-2, 16. Tergal chaetotaxy: 4: 4: 4: 4: 4: 4: 4: 4: 4: 4: T2T: 0 . Sternal chaetotaxy: 2: 4 (without stigmatic microsetae): 4 (without stigmatic microsetae): 6: 6: 6: 6: 6:6:0: 2 . Coxal chaetotaxy of legs: $2: 3: 3: 3$; coxae II with 5 distally incised spines.

Remarks. From the geographically closest species, $L$. tonkinensis (Beier 1951) and L. sinensis (Beier 1967) from China, the new species is easily distinguished by the absence of an epistome and only the fixed chelal finger having tiny intercalary teeth. The new species is most similar to $L$. annamensis (Beier 1951), but can be distinguished from the latter by the chaetotaxy of tergites I and II (four vs. two on each tergite), by the position of trichobothrium $s b$ ( 0.5 times nearer to $s t$ than to $b$ vs. nearly in middle of $b$ and $s t$ ), by the basal teeth of the movable chelal finger (absence vs. a row of flat and low teeth) and by the color of the palpal palm (not darkened vs. darkened). 

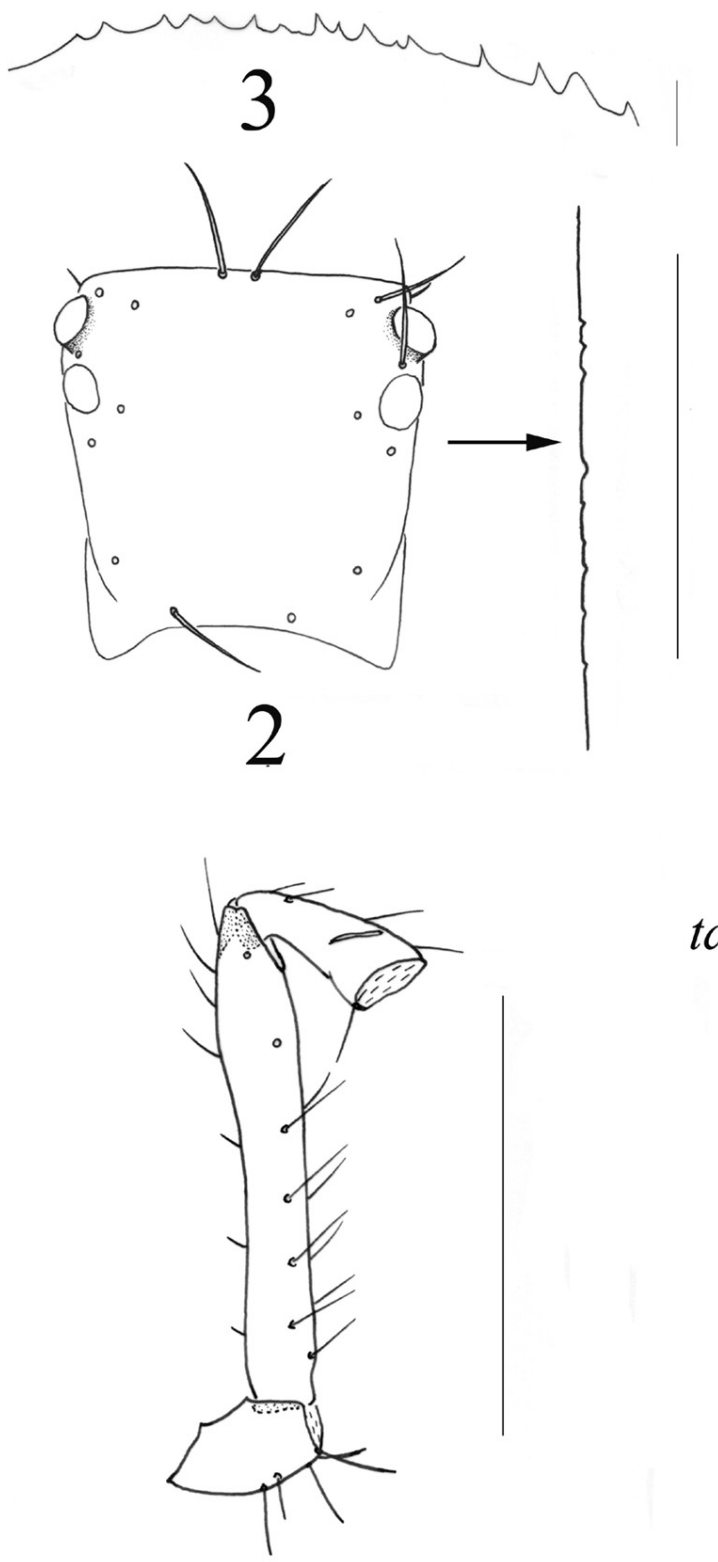

5
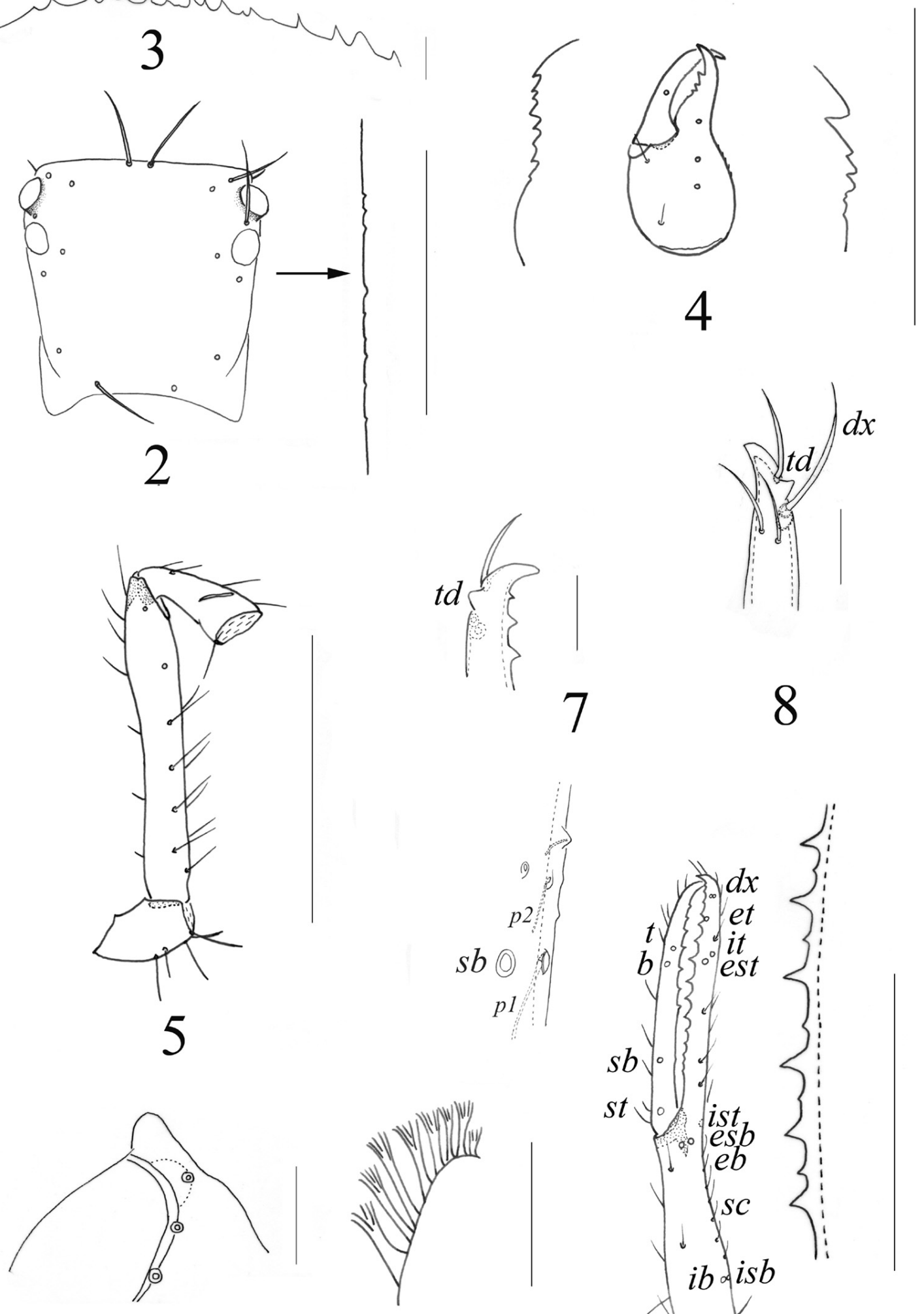

9

10

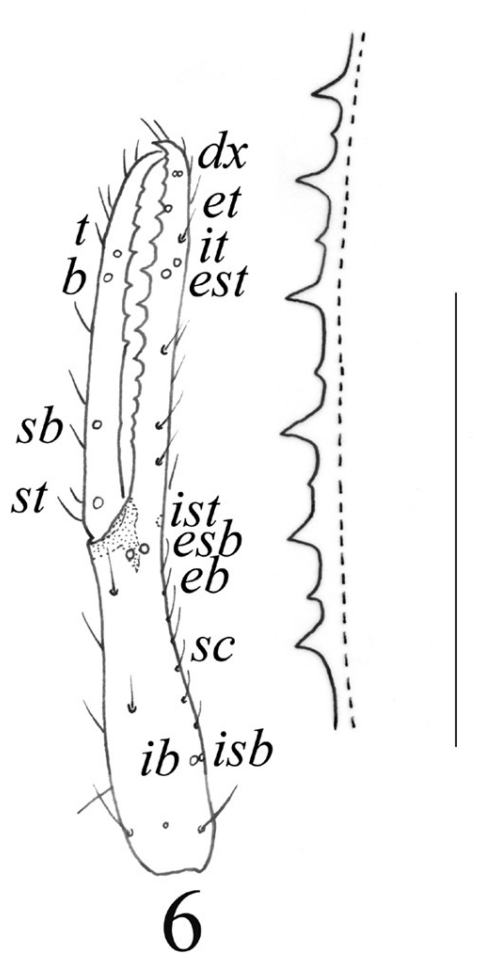

Figs. 2-10. Lagynochthonius microdentatus sp. nov. 2. Carapace; 3. Anterior margin of carapace; 4. Left chelicera; 5. Male palp (minus chela), dorsal view; 6 . Male chela, lateral view, with details of sensilla and dentition; 7. Tip of fixed finger, antiaxial view; 8 . Tip of fixed finger, dorsal view; 9. Process of coxa I; 10. Spines of coxa II. Scales $=0.40 \mathrm{~mm}$ (Figs. 2, 4-6); $0.05 \mathrm{~mm}$ (Figs. 7-10); 0.01 mm (Fig. 3). 


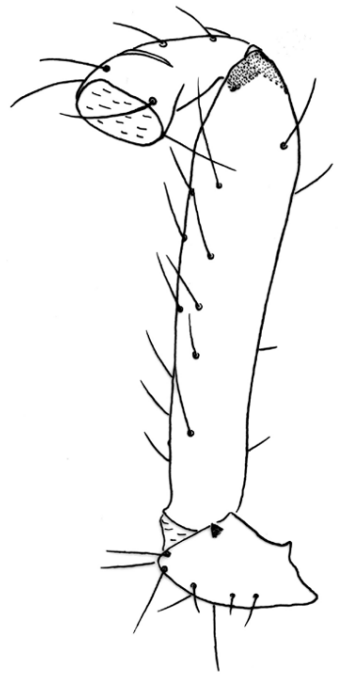

11

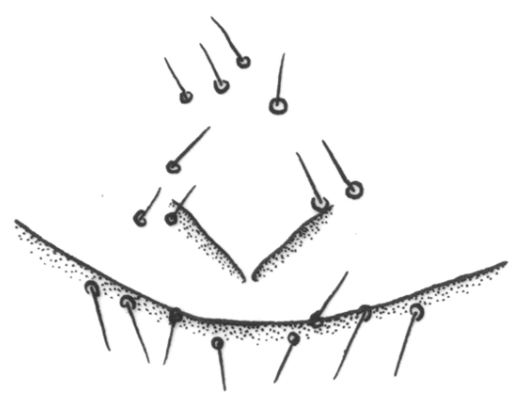

14

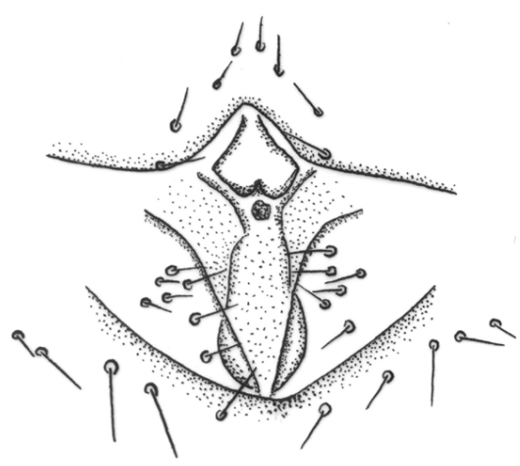

17

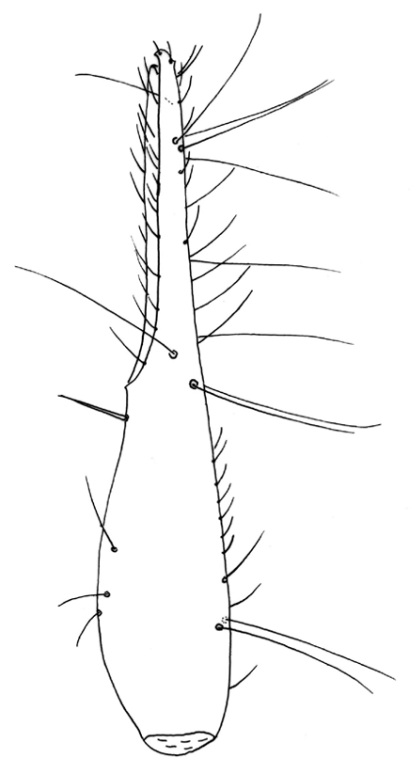

12

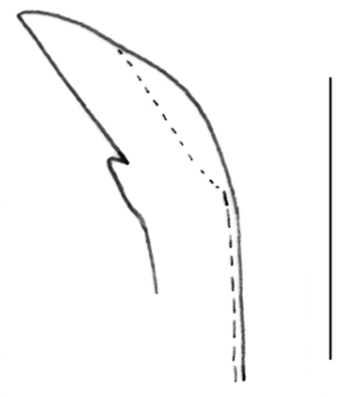

15

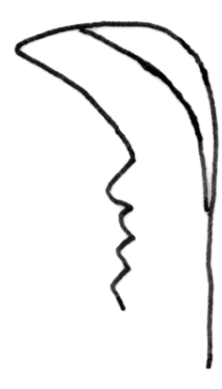

18

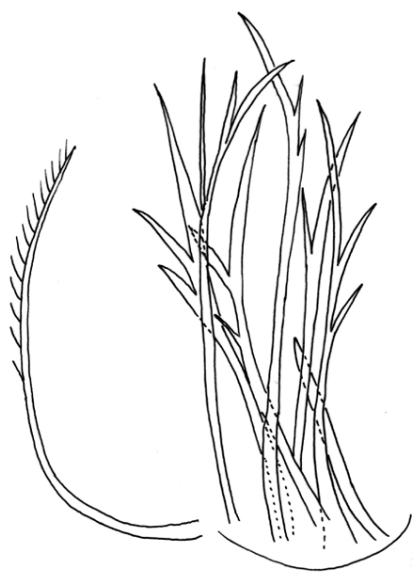

13
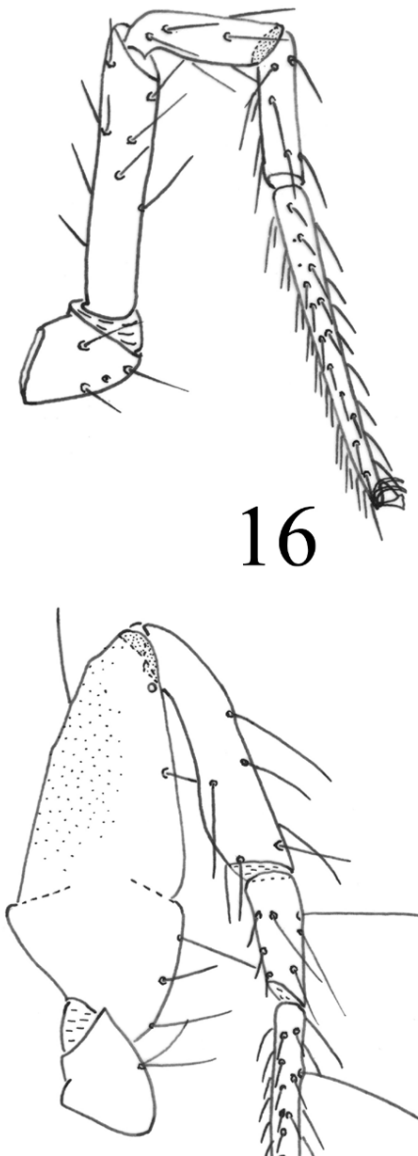

Figs. 11-19. Lagynochthonius microdentatus sp. nov. 11. Female palp (minus chela), dorsal view; 12. Female chela, dorsal view; 13. Rallum; 14. Female genital area; 15. Male galea; 16. Leg I of male; 17. Male genital area; 18. Female galea; 19. Leg IV of male. Scales $=0.5 \mathrm{~mm}$ (Fig. 11); $0.4 \mathrm{~mm}$ (Figs. 12, 14, 16-17, 19); $0.05 \mathrm{~mm}$ (Figs. 13, 15, 18). 
Table 1. Measurements $(\mathrm{mm})$ and proportion of various structures of Lagynochthonius microdentatus sp. nov. Abbreviations: B, breadth; D, depth; L, length.

\begin{tabular}{|c|c|c|c|c|}
\hline & Male & Female & Tritonymph & Deutonymph \\
\hline Body L & $1.08-1.38$ & $1.02-1.60$ & $0.90-1.00$ & 0.60 \\
\hline $\begin{array}{c}\text { Carapace L/B } \\
\text { (Proportion L/B) }\end{array}$ & $\begin{array}{c}0.30^{-0} 0.33 / 0.28-0.31 \\
1.1\end{array}$ & $\begin{array}{c}0.33^{-}-0.37 / 0.35^{-}-0.43 \\
0.8^{-0.9}\end{array}$ & $\begin{array}{c}0.30-0.31 / 0.28 \\
1.0^{-1.1}\end{array}$ & $\begin{array}{c}0.25 / 0.24 \\
1.0\end{array}$ \\
\hline $\begin{array}{c}\text { Chelicera L/B } \\
\text { (Proportion L/B) }\end{array}$ & $\begin{array}{c}0.25-0.27 / 0.13-0.15 \\
1.8-1.9\end{array}$ & $\begin{array}{c}0.32-0.35 / 0.16-0.19 \\
1.9-2.0\end{array}$ & $\begin{array}{c}0.23 / 0.12 \\
1.9\end{array}$ & $\begin{array}{c}0.19 / 0.10 \\
1.9\end{array}$ \\
\hline Movable finger $\mathrm{L}$ & $0.13-0.19$ & $0.16^{-0} 0.19$ & 0.13 & 0.10 \\
\hline $\begin{array}{l}\text { Palpal femur L/B } \\
\text { (Proportion L/B) }\end{array}$ & $\begin{array}{c}0.40^{-} 0.56 / 0.06^{-} 0.10 \\
5.6^{-6.7}\end{array}$ & $\begin{array}{c}0.53-0.60 / 0.09-0.10 \\
5.9-6.0\end{array}$ & $\begin{array}{c}0.35-0.38 / 0.07 \\
5.0-5.4\end{array}$ & $\begin{array}{l}0.20 / 0.05 \\
4.0\end{array}$ \\
\hline $\begin{array}{l}\text { Palpal patella L/B } \\
\text { (Proportion L/B) }\end{array}$ & $\begin{array}{c}0.15^{-0.23 / 0.08-0.10} \\
1.9-2.3\end{array}$ & $\begin{array}{c}0.23-0.25 / 0.10^{-} 0.13 \\
1.9-2.3\end{array}$ & $\begin{array}{c}0.15 / 0.08 \\
1.9 \\
\end{array}$ & $\begin{array}{c}0.10 / 0.07 \\
1.4 \\
\end{array}$ \\
\hline $\begin{array}{l}\text { Palpal chela L/B } \\
\text { (Proportion L/B) }\end{array}$ & $\begin{array}{c}0.58-0.76 / 0.09-0.12 \\
5.8-6.4\end{array}$ & $\begin{array}{c}0.78^{-}-0.88 / 0.14-0.17 \\
5.2-5.6\end{array}$ & $\begin{array}{c}0.50^{-} 0.55 / 0.10^{-} 0.11 \\
5.0\end{array}$ & $\begin{array}{c}0.38 / 0.08 \\
4.8\end{array}$ \\
\hline $\begin{array}{l}\text { Palpal palm L } \\
\text { (Proportion } \mathrm{L} / \mathrm{B} \text { ) }\end{array}$ & $\begin{array}{c}0.25-0.35 \\
2.8-2.9\end{array}$ & $\begin{array}{c}0.35-0.43 \\
2.5-2.6\end{array}$ & $\begin{array}{c}0.21-0.23 \\
1.9-2.1\end{array}$ & $\begin{array}{l}0.17 \\
2.1\end{array}$ \\
\hline Movable finger $\mathrm{L}$ & $0.30-0.40$ & $0.40-0.45$ & $0.28-0.29$ & 0.19 \\
\hline (Proportion finger L/palm L) & $1.1-1.2$ & $1.0-1.1$ & 1.3 & 1.1 \\
\hline $\begin{array}{c}\text { Femur I L/D } \\
\text { (Proportion L/D) }\end{array}$ & $\begin{array}{c}0.25^{-0.29 / 0.05-0.08} \\
3.6^{-5.0}\end{array}$ & $\begin{array}{c}0.28-0.33 / 0.06 \\
4.7-5.5\end{array}$ & $\begin{array}{l}0.18-0.20 / 0.05 \\
3.6^{-4.0}\end{array}$ & $\begin{array}{c}0.15 / 0.04 \\
3.8\end{array}$ \\
\hline $\begin{array}{c}\text { Patella I L/D } \\
\text { (Proportion L/D) }\end{array}$ & $\begin{array}{c}0.13-0.14 / 0.05 \\
2.6^{-}-2.8 \\
\end{array}$ & $\begin{array}{c}0.15^{-0.18 / 0.05-0.06} \\
3.0 \\
\end{array}$ & $\begin{array}{c}0.10-0.12 / 0.04 \\
2.5-3.0\end{array}$ & $\begin{array}{c}0.08 / 0.04 \\
2.0\end{array}$ \\
\hline $\begin{array}{c}\text { Tibia I L/D } \\
\text { (Proportion L/D) }\end{array}$ & $\begin{array}{c}0.13-0.16 / 0.04-0.05 \\
3.3-3.8 \\
\end{array}$ & $\begin{array}{c}0.15-0.18 / 0.04 \\
3.8-4.5 \\
\end{array}$ & $\begin{array}{c}0.10^{-0.11 / 0.03-0.04} \\
2.8^{-3.3} \\
\end{array}$ & $\begin{array}{c}0.08 / 0.03 \\
2.7\end{array}$ \\
\hline $\begin{array}{c}\text { Tarsus I L/D } \\
\text { (Proportion L/D) }\end{array}$ & $\begin{array}{c}0.28-0.33 / 0.03 \\
9.3-11.0\end{array}$ & $\begin{array}{c}0.34-0.38 / 0.03-0.04 \\
9.5^{-11.3}\end{array}$ & $\begin{array}{c}0.20-0.23 / 0.03 \\
6.7-7.7\end{array}$ & $\begin{array}{c}0.18 / 0.03 \\
6.0\end{array}$ \\
\hline $\begin{array}{l}\text { Femur }+ \text { patella IV L/D } \\
\text { (Proportion L/D) }\end{array}$ & $\begin{array}{l}0.40-0.52 / 0.15-0.19 \\
2.7\end{array}$ & $\begin{array}{c}0.45-0.58 / 0.18-0.20 \\
2.5-2.9\end{array}$ & $\begin{array}{c}0.30-0.33 / 0.12-0.13 \\
2.5\end{array}$ & $\begin{array}{c}0.19 / 0.09 \\
2.1\end{array}$ \\
\hline $\begin{array}{l}\text { Tibia IV L/D } \\
\text { (Proportion L/D) }\end{array}$ & $\begin{array}{c}0.28-0.33 / 0.05-0.08 \\
4.1-5.6\end{array}$ & $\begin{array}{c}0.28-0.40 / 0.07-0.08 \\
4.0-5.0\end{array}$ & $\begin{array}{c}0.20-0.21 / 0.05-0.06 \\
3.5-4.0\end{array}$ & $\begin{array}{c}0.14 / 0.05 \\
2.8\end{array}$ \\
\hline $\begin{array}{l}\text { Basitarsus IV L/D } \\
\text { (Proportion L/D) }\end{array}$ & $\begin{array}{c}0.13-0.16 / 0.04-0.05 \\
3.2-3.3\end{array}$ & $\begin{array}{c}0.14-0.20 / 0.05-0.06 \\
2.8-3.3\end{array}$ & $\begin{array}{c}0.10 / 0.04-0.05 \\
2.0-2.5\end{array}$ & $\begin{array}{c}0.07 / 0.04 \\
1.8\end{array}$ \\
\hline $\begin{array}{l}\text { Telotarsus IV L/D } \\
\text { (Proportion L/D) }\end{array}$ & $\begin{array}{c}0.33^{-0.39 / 0.03-0.04} \\
9.8^{-11.0}\end{array}$ & $\begin{array}{c}0.38-0.43 / 0.03-0.04 \\
10.8^{-12.7}\end{array}$ & $\begin{array}{c}0.23-0.25 / 0.03-0.04 \\
6.3-7.7\end{array}$ & $\begin{array}{c}0.18 / 0.03 \\
6.0\end{array}$ \\
\hline
\end{tabular}

\section{Acknowledgments}

We heartily express our thanks to Prof. Volker Mahnert (Muséum d'Histoire naturelle, Geneva) for his kind help to us in our work, and we also express thanks to Dr. Mark. S. Harvey (Western Australian Museum, Perth, Australia) for kindly donating valuable literature. Helpful comments on the manuscript were provided by two anonymous referees. This work was supported by the National Natural Science Foundation of China (No. 31071885, 30970325, 31093430).

\section{References}

Beier, M. 1951. Die Pseudoscorpione Indochinas. Mémoires du Muséum National d'Histoire Naturelle, Paris, nouvelle série, 1: 47123.

Chamberlin, J. C. 1931. The arachnid order Chelonethida. Stanford University Publications, Biological Sciences, 7(1): 1-284.
Harvey, M. S. 1992. The phylogeny and classification of the Pseudoscorpionida (Chelicerata: Arachnida). Invertebrate Taxonomy, 6: 1373-1435.

Harvey, M. S. 2011. Pseudoscorpions of the World, ver-sion 2.0. - Western Australian Museum, [www docu-ment]. URL http://www.museum.wa.gov.au/catalo-gues/pseudoscorpions. (Site visited on 2 March, 2012)

Judson, M. L. I. 2007. A new and endangered species of the pseudoscorpion genus Lagynochthonius from a cave in Vietnam, with notes on chelal morphology and the composition of the Tyrannochthoniini (Arachnida, Chelonethi, Chthoniidae). Zootaxa, 1627: $53-68$

Received May 3, 2011 / Accepted May 19, 2012 